have suggested that archaic immune genes may have helped $H$. sapiens to cope with diseases that they encountered outside Africa.

Also at the meeting, a team led by Michael Dannemann, a computational biologist at the Max Planck Institute for Evolutionary Anthropology in Leipzig, Germany, reported that many humans have Neanderthal and Denisovan versions of genes that encode proteins called toll-like receptors (TLRs), which sense pathogens and launch a rapid immune response. Furthermore, cultured human cells containing the archaic versions tended to express the TLRs at higher levels than cells with the $H$. sapiens versions ${ }^{7}$. Although previous GWAS linked the archaic versions to a reduced risk of Heliobacter pylori infection, which can cause stomach ulcers, the variants were also associated with higher rates of allergies.

"Many traits that were adaptive 10,000 years ago might be maladaptive today" because of lifestyle, diet and other shifts, notes Rasmus Nielsen, a population geneticist at the University of California, Berkeley.

At least one archaic trait has clear benefits in contemporary humans. Last year, Nielsen's team reported that the Denisovan-like version of a gene called EPAS1 helps modern Tibetans to cope with life at altitudes of 4,000 metres, by preventing their blood from thickening ${ }^{8}$.

Many researchers see Nielsen's EPAS1 discovery as the poster child for humans' archaic biology, because the benefits of the Denisovan version are so clear-cut. But proving such insights rests on laborious studies, including engineering mice to carry the archaic mutations and exhaustively testing the animals' biology, notes Reich. "Each new finding is going to be very hard won." -

1. Green, R. E. et al. Science 328, 710-722 (2010).

2. Meyer, M. et al. Science 338, 222-226 (2012).

3. Rasmuseen, M. et al. Science 334, 94-98 (2011).

4. Hammer, M. F., Woerner, A. E., Mendez, F. L.,

Watkins, J. C. \& Wall, J. D. Proc. Natl Acad. Sci. USA 108, 15123-15128 (2011).

5. Vernot, B. \& Akey, J. M. Science 343, 1017-1021 (2014)

6. Sankararaman, S. et al. Nature 507, 354-357 (2014).

7. Dannemann, M., Andrés, A. M. \& Kelso, J. Preprint at http://dx.doi.org/10.1101/022699 (2015).

8. Huerta-Sánchez, E. et al. Nature 512, 194-197 (2014).

\title{
Budget showdown leaves US science agencies in limbo
}

\section{Lawmakers face looming deadline to reach a deal - or risk government shutdown.}

\section{BY CHRIS CESARE}

$\mathrm{W}$ hen the US Congress returns from its late-summer recess in early September, lawmakers and President Barack Obama will have less than three weeks to reach a budget deal for 2016, and in doing so determine the funding of key science agencies.

The most likely scenario, experts say, is that a temporary deal will be made to keep the government operating for weeks or months after the 2016 fiscal year begins on 1 October. That is cold comfort for US science agencies and researchers who have endured years of bruising partisan spending battles.

"We're basically headed into a period of frustration where nothing's going to happen for a couple months, and we're just going to have to deal with it," says Jennifer Zeitzer, director of legislative relations at the Federation of American Societies for Experimental Biology in Bethesda, Maryland.

The current funding agreement expires on 30 September. And, in protest against legislators' embrace of the across-the-board budget cuts known as sequestration, Obama has threatened to veto many of the 2016 spending bills introduced by the Republican-controlled House of Representatives and Senate.

Some agencies, such as the National Institutes of Health (NIH), seem likely to emerge as winners in any deal (see 'Budget battle'). The House has proposed increasing the NIH budget by US\$1.1 billion in

BUDGET BATTLE

How funding proposals from the White House and Congress stack up, by agency (US\$ millions).

\begin{tabular}{|c|c|c|c|c|}
\hline Agency & $\begin{array}{c}2015 \text { estimated } \\
\text { budget }\end{array}$ & $\begin{array}{l}2016 \text { White } \\
\text { House request }\end{array}$ & $\begin{array}{l}2016 \text { House } \\
\text { bill }\end{array}$ & $\begin{array}{l}2016 \text { Senate } \\
\text { bill }\end{array}$ \\
\hline \multicolumn{5}{|c|}{ Biomedical research and public health } \\
\hline National Institutes of Health & 30,311 & 31,311 & 31,184 & 32,084 \\
\hline $\begin{array}{l}\text { Centers for Disease Control } \\
\text { and Prevention }\end{array}$ & 6,073 & 6,170 & 7,010 & 6,711 \\
\hline $\begin{array}{l}\text { Food and Drug } \\
\text { Administration }\end{array}$ & 2,596 & 2,744 & 2,619 & 2,629 \\
\hline \multicolumn{5}{|l|}{ Physical sciences } \\
\hline National Science Foundation & 7,344 & 7,724 & 7,394 & 7,344 \\
\hline NASA (science) & 5,245 & 5,289 & 5,238 & 5,295 \\
\hline $\begin{array}{l}\text { Department of Energy Office } \\
\text { of Science }\end{array}$ & 5,068 & 5,340 & 5,100 & 5,100 \\
\hline $\begin{array}{l}\text { National Institute of } \\
\text { Standards and Technology }\end{array}$ & 864 & 1,120 & 855 & 893 \\
\hline \multicolumn{5}{|l|}{ Earth and environment } \\
\hline $\begin{array}{l}\text { Environmental Protection } \\
\text { Agency }\end{array}$ & 8,140 & 8,592 & 7,422 & 7,597 \\
\hline $\begin{array}{l}\text { National Oceanic and } \\
\text { Atmospheric Administration }\end{array}$ & 5,449 & 5,983 & 5,167 & 5,382 \\
\hline US Geological Survey & 1,045 & 1,195 & 1,045 & 1,059 \\
\hline
\end{tabular}

2016 , to $\$ 31.2$ billion; the Senate's proposal of $\$ 32.1$ billion is even more generous. And both are close to the White House proposal of $\$ 31.3$ billion.

But for other agencies and programmes, the prospects are not so clear. The House matched Obama's \$18.5-billion request for NASA, and the Senate is close at $\$ 18.3$ billion.
But the House wants to chop \$101 million from the space agency's \$1.8-billion Earthsciences account, which funds research on topics such as climate change. The Senate would boost the wing's funding by roughly $\$ 148$ million. Similarly, the House bill would set aside $\$ 5.2$ billion for the National Oceanic and Atmospheric Administration 
- (NOAA), $5 \%$ less than the current level and about $\$ 800$ million short of Obama's request. The Senate bill would reduce NOAA spending by just $1 \%$.

But it is the National Science Foundation (NSF) that has most polarized lawmakers. The House's NSF spending bill would require the agency to award $70 \%$ of its \$6-billion research fund to biology, computer science, engineering, mathematics and the physical sciences. The unusual provision would effectively impose a $16 \%$ cut to geoscience and social-sciences programmes, according to an analysis by the American Institute of Physics. By contrast, the Senate's bill does not set funding levels for particular disciplines.

\section{BASIC FOCUS}

Powerful House Republicans, most notably science-committee chair Lamar Smith of Texas, have argued that the NSF should concentrate on basic research. Smith has also tried to highlight what he sees as questionable grants by the science agency, such as funding for a study of mental health in Nepal. But Gloria Waters, vice-president and associate provost for research at Boston University in Massachusetts, says that legislators often misunderstand the role of basic science. "People have this idea that science funding should go to something that should have an immediate and direct impact on society, but that's not how science works," she says.

Deciding which projects to fund is made more difficult by a lack of money, says Hannah Carey, a physiologist at the University of Wisconsin-Madison. "I've experienced it - you put in a grant to continue your work that gets a very, very good score and would have been funded in a better climate," says Carey, who spent a year working as a programme director in the NSF's biosciences division. "It's disheartening."

A short-term spending deal would avert a government shutdown of the sort that ground most research to a halt in October 2013. But a stopgap arrangement could still make life difficult for researchers. Such deals generally prevent agencies from starting new programmes or ending old ones without specific authorization from Congress. And agencies can face unexpected budget shortfalls if lawmakers agree to cut spending after months of operating under a temporary funding agreement, because the cuts would be retroactive.

For now, scientists are left to wait while the negotiations between Congress and the White House play out. Zeitzer says that a deal may not be struck until the last minute. "I'm hearing there's a real good chance they'll take us to the brink," she says.

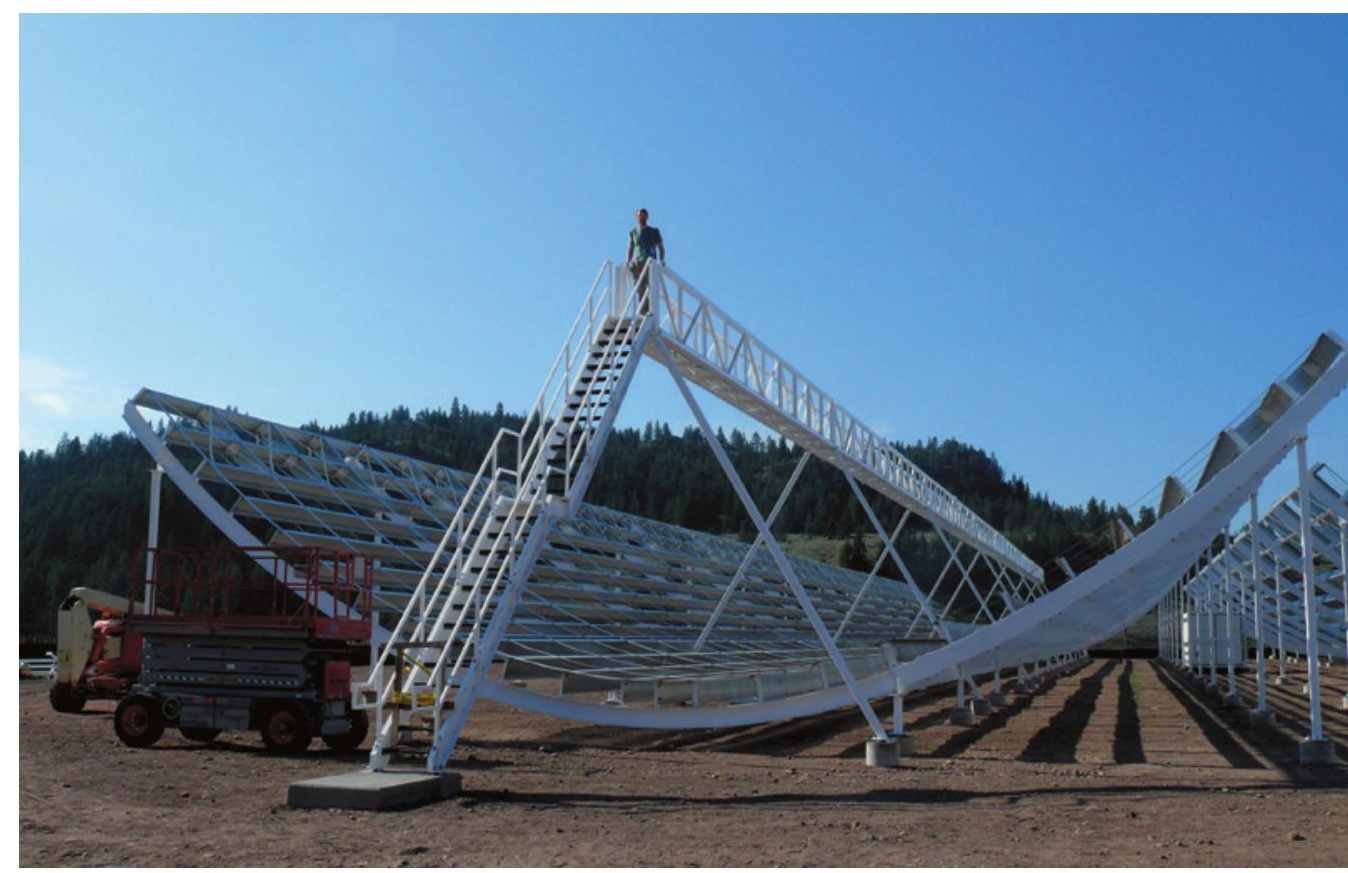

The CHIME telescope array will search for a particular kind of hydrogen emission from ancient galaxies.

\section{COSMOLOGY}

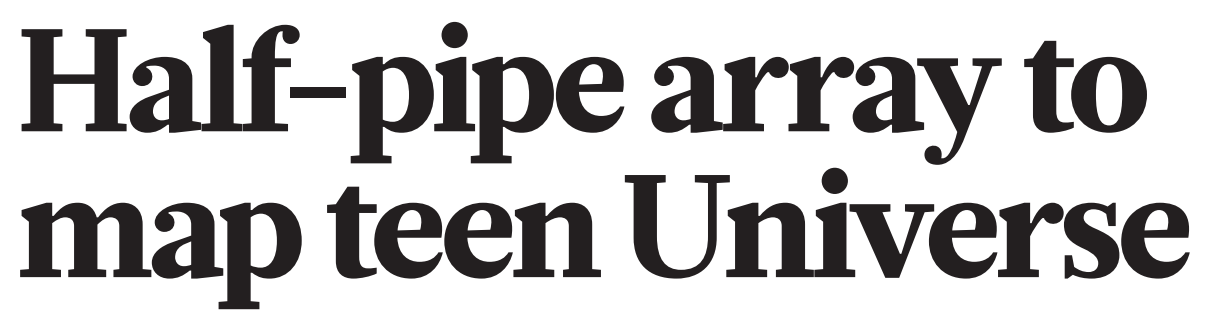

\section{Canadian telescope aims to chart cosmic expansion rate between 10 billion and 8 billion years ago.}

\section{BY DAVIDE CASTELVECCHI}

I t sounds almost too apt to be true. An observatory shaped like the half-pipes used by snowboarders, and dependent on technology originally designed for gaming and mobile phones, will soon be tasked with plugging a crucial gap in the cosmological record: what the Universe did when it was a teenager.

The information will allow cosmologists to gauge whether the strength of dark energy the force accelerating the Universe's expansion - has changed over time, an unresolved question that governs the fate of the cosmos.

Whereas typical radio telescopes have round dishes, the Canadian Hydrogen Intensity Mapping Experiment (CHIME) comprises four 100-metre-long, semi-cylindrical antennas, which lie near the town of Penticton in British Columbia.

From 2016, CHIME's half-pipes, which are scheduled to be completed this week, will detect radio waves emitted by hydrogen in distant galaxies. These observations would be the first measurements of the Universe's expansion rate between 10 billion and 8 billion years ago, a period in which the cosmos went "from being a kid to an adult", says Mark Halpern, the leader of CHIME and an experimental cosmologist at the University of British Columbia in Vancouver. Straight after the Big Bang 13.8 billion years ago, the rate of the Universe's expansion slowed. But somewhere during the 'adolescent' period, dark energy which eventually turned the Universe's slowing expansion into the acceleration observed today - began to be felt, he says.

It is a window in time that has, until now, been closed. Cosmologists measure the Universe's past expansion rate using ancient objects, such as supernova explosions and the voids between galaxies, that are so distant that their light is only now reaching Earth. Over the past few decades, such objects have revealed that the cosmos has been expanding at an accelerating rate for more than 6 billion years. And surveys of quasars mysterious, super-bright objects that outshine the entire galaxies they lie in - have shown that until 10 billion years or so ago, the Universe's expansion was slowing down. 